JoIE: Journal of Islamic Economics | Husna Ni'matul Ulya

\title{
Pemulihan Perekonomian Jawa Timur di Masa Pandemi Covid-19 Melalui \\ Sistem Pertanian Terpadu (SPT) Budikdamber (Budidaya Ikan dalam \\ Ember)
}

\author{
Husna Ni'matul Ulya \\ Institut Agama Islam negeri Ponorogo, Indonesia \\ husna@iainponorogo.ac.id
}

\begin{abstract}
Abstrak: Penurunan pertumbuhan ekonomi Indonesia selama masa pandemi covid-19 terjadi selama kuartal I dan kuartal II menyebabkan melemahnya laju perekonomian dan menurunnya pendapatan masyarakat, dikarenakan kebijakan pemerintah dalam pencegahan penyebaran covid-19 berupa Pembatasan Sosial Berskala Besar (PSBB), penerapan protokol kesehatan, dan Learn/Work From Home (LFH/WFH), sehingga masyarakat harus tetap berada di rumah dan mengurangi aktifitas di luar jika tidak dibutuhkan. Dampak yang terjadi mempengaruhi semua bidang perekonomian, salah satunya pada sektor/lapangan usaha pertanian. Perkembangan perekonomian propinsi Jawa Timur juga mengalami penurunan pada data terakhir sebesar 5,90\%. Di antara sektor yang mengalami penurunan, sektor pertanian adalah sektor yang masih mengalami pertumbuhan positif, karena produktifitas sektor pertanian tidak begitu dipengaruhi oleh situasi pendemi, namun yang menjadi masalah adalah jumlah permintaan yang lebih menurun daripada sebelumnya. Untuk memberikan solusi terhadap kebijakan pandemi, maka diperlukan Sistem Pertanian Terpadu (SPT) yang memanfaatkan lahan di sekitar rumah, sehingga masyarakat tidak perlu keluar rumah untuk bertani. Selain dapat mencukupi kebutuhan pangan keluarga, masyarakat dapat menjual hasil panennya, tidak hanya mencukupi kebutuhan nabati, tapi juga kebutuhan hewani. Sistem yang diadopsi dari program dompet dhuafa yang disebut Budidaya Ikan dalam Ember (budikdamber) menjadi salah satu pilihan untuk memenuhi sistem pertanian terpadu, karena selain memanfaatkan seumberdaya yang ada, juga dapat memaksimalkan penggunaan media yang sama untuk dua sistem budidaya. Namun, masih banyak yang harus dilaksanakan untuk menindaklanjuti pengembangan sistem ini yang disesuaikan dengan tuntutan perkembangan sosial, budaya, teknologi dan ekonomi masyarakat.
\end{abstract}

Kata Kunci: Budikdamber, sistem pertanian terpadu, pandemi.

Abstract: The decline in Indonesia's economic growth during the Covid-19 pandemi occurred during the first quarter and second quarter which caused a weakening of the economy and decreased people's income, due to government policies to prevent the spread of Covid-19 in the form of Large-Scale Social Restrictions (PSBB), implementation of health protocols, and Learn / Work From Home (LFH / WFH), so that people must stay at home and reduce outdoor activities 
when not needed. The impact that occurs affects all sectors of the economy, one of which is the agricultural sector/business field. The economic development of East Java province also experienced a decline in the latest data of $5.90 \%$. Among the sectors that have experienced a decline, the agricultural sector is still experiencing positive growth, because the productivity of the agricultural sector is not significantly affected by the pandemi situation, but the problem is that the amount of demand is decreasing more than before. To provide solutions to pandemi policies, an Integrated Farrming System (IFS) are needed which utilizes the land around the house, so that people don't have to leave the house to the farm. In addition to being able to meet family food needs, people can sell their crops, not only for vegetable needs but also for animal needs. The system adopted from the dompet dhuafa program called Aquaculture in a Bucket (budikdamber) is an option to fulfill an integrated agricultural system because, in addition to utilizing existing resources, it can also maximize the use of the same media for two cultivation systems. However, much remains to be done to follow up on the development of this system in line with the demands of social, cultural, technological, and economic development in society.

Keyword: Budikdamber, integrated farming system, pandemic.

\section{JEL Classification Numbers: 013}

\section{PENDAHULUAN}

Pandemi Covid-19 telah menimbulkan banyak dampak pada segala bidang. Salah satu dampak terjadi pada tingkat ekonomi dan kesejahteraan masyarakat, khususnya di provinsi Jawa Timur. Pertumbuhan ekonomi Jawa Timur pada triwulan I 2020 mencapai 3,04\% (yoy), lebih rendah dibandingkan triwulan IV 2019 yang sebesar 5,54\% (yoy), meskipun demikian masih lebih tinggi dibandingkan Nasional yang sebesar 2,97\% (yoy). Dari sisi permintaan, perlambatan pertumbuhan terutama disebabkan oleh menurunnya kinerja konsumsi swasta serta net ekspor akibat regulasi pembatasan ekonomi yang antara lain berdampak pada penyesuaian konsumsi masyarakat serta penurunan permintaan mitra dagang domestik Jawa Timur. Dari sisi penawaran, perlambatan kinerja ekonomi Jawa Timur pada triwulan I 2020 terutama disebabkan perlambatan lapangan usaha utama Jawa Timur yaitu Industri Pengolahan serta Perdagangan Besar dan Eceran; Reparasi Mobil dan Sepeda Motor sebagai respon atas rendahnya konsumsi domestik. Sementara gangguan produksi akibat tingginya curah hujan berdampak pada penurunan kinerja Pertanian. Perlambatan kinerja yang lebih 
JoIE: Journal of Islamic Economics | Husna Ni'matul Ulya

dalam tertahan oleh peningkatan kinerja lapangan usaha Jasa Kesehatan dan Kegiatan Sosial sejalan dengan peningkatan permintaan pada sektor kesehatan akibat pandemi COVID-10. Lapangan usaha Informasi dan Komunikasi juga meningkat seiring kenaikan permintaan akibat kebijakan Work from Home (WFH) dan School from Home (SFH) (www.bi.go.id).

Pada triwulan II 2020 kinerja ekonomi Jawa Timur diperkirakan akan meningkat positif meskipun lebih lambat dibandingkan triwulan I 2020 seiring pelaksanaan PSBB di Jawa Timur yang semakin ketat. Kinerja konsumsi rumah tangga pada periode ini semakin tertekan akibat penerapan PSBB di berbagai daerah yang menyebabkan semakin banyaknya pekerja yang dirumahkan maupun di PHK, terbitnya Surat Edaran Menteri Tenaga Kerja kepada Kepala Daerah yang mengizinkan pembayaran THR yang bertahap hingga akhir tahun 2020, serta perilaku rumah tangga yang menahan konsumsi, khususnya yang berpendapatan menengah ke atas (www.bi.go.id). Proyeksi akan berbeda pada triwulan ke III yang apabila dibiarkan pertumbuhan ekonomi pada nilai negatif, maka kemungkinan akan terjadi resesi di negara Indonesia (kompas.id).

Peran sektor pertanian di Negara sedang berkembang sangat penting, karena mayoritas penduduk miskin menggantungkan hidup mereka pada sektor ini. Indonesia adalah salah satu Negara yang total pendapatan nasional memiliki ketergantungan yang besar di sektor pertanian, sebagian penduduk Indonesia masih bergantung pada sektor pertanian. Menurut Badan Pusat Statistik Nilai Tukar Petani (NTP) Jawa Timur Bulan Mei 2020 turun 0,42 persen dari 99,43 menjadi 99,01. Subsektor yang mengalami penurunan NTP terbesar terjadi pada subsektor Hortikultura sebesar 2,44 persen dari 100,41 menjadi 97,96, diikuti subsektor tanaman pangan sebesar 0,20 persen dari 100,48 menjadi 100,28 . Secara umum indeks harga yang diterima petani (It) mengalami penurunan lebih tinggi dibandingkan dengan indeks harga yang dibayar petani (Ib). Indeks harga yang diterima petani (It) turun sebesar 0,57 persen, sedangkan indeks harga yang dibayar petani (Ib) sebesar 0,15 persen. Penurunan tersebut diakibatkan tidak dapat dipasarkan produk hortikultura, maupun tanaman pangan sehingga petani sebagai produsen pangan lebih banyak mengeluarkan biaya produksi daripada pendapatan 
yang diterimanya (www.kementan.go.id.). Data lain menyebutkan sektor pertanian Jawa Timur mencatatkan pertumbuhan tertinggi dari sisi produksi sebesar 27,26 persen di Triwulan II 2020. meskipun ekonomi Jatim pada triwulan II 2020 terkontraksi 5,90 persen dibandingkan triwulan II 2019 (yoy) (suarasurabaya.net). oleh karena itu potensi tersebut bisa dikembangkan untuk memberikan upaya untuk memulihkan perekonomian Jawa Timur yang diakibatkan oleh kebijakan saat pandemi, diantaranya dengan memaksimalkan potensi lahan di sekitar rumah dengan menerapkan Sistem Pertanian Terpadu (SPT) organik, dimana hal ini bertujuan untuk menguatkan ketahanan pangan keluarga dan dapat dipasarkan untuk menambah pendapatan bagi masyarakat. Dompet dhuafa yang merupakan salah satu lembaga sosial telah melaksanakan sosialisasi mengenai sistem budidaya ikan di dalam ember dengan cara memelihara ikan lele dan sayuran dalam wadah yang sama. Sistem ini tentunya juga dibutuhkan sistem pemasaran online yang dapat menyesuaikan kondisi pendemi.

Artikel ini mencoba menjelaskan data sekunder tentang gambaran data perkembangan pertumbuhan ekonomi khususnya pada lembaga usaha pertanian di Jawa Timur, dan menjelaskan tentang sistem pertanian terpadu dengan sistem budidaya ikan dalam ember yang dapat menjadi salah satu solusi bagi pemulihan ekonomi Jawa Timur akibat pendemi covid-19.

\section{TINJAUAN LITERATUR}

Studi ini menjelaskan tentang pandemi covid-19 yang memberikan dampak yang berbeda bagi segala bidang. Pertumbuhan ekonomi yang menurun berdampak pada segala bidang dijelaskan oleh Hanoatubun (2020), setelah adanya masalah covid-19 mengakibatkan perekonomian indonesia menurun sampai 5\% atau akan mendekati yang lebih rendah, selain itu kinerja investasi, sektor keuangan, pariwisata, pertanian, industri mengalami depresiasi perekonomian.

Untuk mengatasi masalah perekonomian adalah dengan menerapkan budikdamber, seperti penelitian yang dilakukan oleh Perwitasari et.al. (2019) di Desa Gending Probolinggo yang mayoritas penduduk memiliki mata pencaharian sebagai peternak. Penerapan budikdamber sebagai pengembangan dari sistem 
akuaponik diharapkan mampu menumbuhkan minat masyarakat kembali dalam melakukan budidaya ikan dan sayuran dalam satu tempat, sehingga hasil panen yang didapat pun berlimpah serta mencukupi kebutuhan gizi yang berasal dari ikan dan sayuran. Salah satu upaya untuk mengembangkan kembali potensi lokal berupa budidaya ikan lele, perlu dilakukan sebuah tindakan berupa sosialisasi. Tujuan budikdamber ini adalah mengisi waktu luang serta mengembangkan kemampuan budidaya ikan lele yang dulu pernah memelihara, selain itu juga sebagai bentuk pemanfaatan pekarangan rumah atau lahan sempit menjadi efisien dan menguntungkan.

Menurut Susetya et.al. (2018) kegiatan pengembangan budikdamber dilakukan kegiatan penyuluhan tentang budikdamber, pemberian modul, pemberian alat dan bahan untuk kegiatan budidaya termasuk bibit ikan, sayur dan pelet ikan. Hasil yang dirasakan oleh mitra pengabdian adalah panen Ikan Lele mulai dari 2 bulan pemeliharaan sampai bulan ke-4 pemeliharaan. Panen sayur kangkung dimulai dari 2 minggu pemeliharaan sampai bulan ke-4 pemeliharaan dengan ratarata jumlah panen 1 ikat untuk setiap ember. Hal yang sama dijelaskan oleh Saputri et.al. (2020) bahwa dengan adanya penemuan teknik pertanian dan perikanan yang sedeharhan yaitu bukdidamber plus akuaponik diharap bisa membantu menghadapi permasalahan saat ini. Pemerintah memberikan pelatihan dan pembiayaan pada masyarakat untuk mengembangkan bukdidamber. Para masyarakat yang berhasil dengan teknik bukdidamber mampu menciptakan peluang usaha dan menambah pengahasilan ditengah masa pandemi covid 19 seperti sekarang. Dengan memperkuat umkm maka beban pemerintah menjadi sedikit berkurang

Studi pada artikel ini adalah mengadopsi dari penelitian sebelumnya, dan menerapkannya pada seluruh wilayah di Jawa Timur, untuk mewujudkan ketahanan pangan dan peningkatan

\section{Pembangunan Pertanian}

Sektor pertanian merupakan sektor yang berperan penting di negara yang sedang berkembang. Pembangunan pertanian diarahkan pada berkembangnya pertanian yang maju, efisien dan tangguh. Pengertian maju, efisien dan tangguh dalam ekonomi pertanian menurut Mubyarto (1989) mencakup konsep-konsep 
mikro dan makro yaitu bagi sektor pertanian sendiri maupun dalam hubungannya dengan sektor-sektor lain diluar pertanian, misalnya industri, transportasi, perdagangan dan keuangan/ perkreditan. Selanjutnya pembangunan pertanian bertujuan untuk meningkatkan hasil dan mutu produksi, meningkatkan pendapatan dan taraf hidup petani, peternak dan nelayan, memperluas lapangan kerja dan kesempatan berusaha, menunjang pembangunan industri serta meningkatkan ekspor.

Menurut Asriani (2003) dalam upaya perwujudan konsep pembangunan pertanian berkelanjutan di Indonesia, diperkirakan akan terwujud melalui pendekatan strategi pembangunan agribisnis nasional adalah:

1. Mendorong perkembangan agribisnis dengan agroindustri. Pada saat etika orientasi pembangunan pertanian terletak pada peningkatan produksi, yang menjadi motor penggerak sektor agribisnis adalah usahatani. Dewasa ini dan di masa yang akan datang, orientasi sektor telah berubah kepada orientasi pasar, dengan berlangsungnya perubahan preferensi konsumen yang semakin menuntut atribut produk yang lebih rinci dan lengkap, maka motor penggerak sektor agribisnis harus berubah dari usahatani kepada industri pengolahan (agroindustri).

2. Intensifikasi strategi pemasaran. Pembangunan sektor agribisnis yang berorientasi pasar menyebabkan strategi pemasaran menjadi sangat penting, bahkan paling menentukan keberhasilan. Pengembangan strategi pemasaran ini semakin penting peranannya terutama mengahadapi masa depan, dimana preferensi konsumen terus mengalami perubahan.

3. Inovasi dan pengembangan sumberdaya pertanian/agribisnis. Agar sektor agribisnis mampu menyesuaikan diri terhadap perubahan pasar, diperlukan pengembangan sumber daya agribisnis, khususnya pemanfaatan dan pengembangan teknologi, serta pembangunan kemampuan sumber daya manusia agribisnis sebagai aktor pengembangan sektor agribisnis.

4. Restrukturisasi tata kelola agribisnis. Struktur agribisnis nasional yang terkotak-kotak telah menciptakan transmisi dan margin ganda, yang secara keseluruhan akan merugikan perkembangan sektor agribisnis nasional. Oleh 
sebab itu, penataan dan pengembangan sektor agribisnis perlu memperoleh perhatian yang serius. Penetaan dan pengembangan struktur agribisnis nasional diarahkan pada dua sasaran pokok, yaitu (1) mengembangkan struktur agribisnis yang terintegrasi secara vertikal mengikuti satu aliran produk (produk line) sehingga subsistem agribisnis hulu, subsistem agribisnis pertanian primer dan subsistem agribisnis hilir beradadalam suatu keputusan manajemen; (2) mengembangkan organisasi bisni (ekonomi) petani agar dapat merebut nilai tambah yang ada pada sub sistem agribisnis hulu dan subsistem agribisnis hilir.

5. Pengembangan pusat pertumbuhan agribisnis. Selama ini, lokasi perkembangan agroindustri nasional umumnya berorientasi pada konsentrasi konsumen seperti sektor perkotaan dan di pulau jawa yang merupakan pusat-pusat konsumen. Di masa yang akan datang, orientasi lokasi agroindustri tersebut telah diubah. Dari orientasi pusat-pusat konsumen ke orientasi sentraproduksi bahan baku.

6. Pengembangan infrastruktur agribisnis. Dalam upaya mendukung pengembangan pusat-pusat pertumbuhan sektor agribisnis tersebut, diperlukan pengembangan infrastruktur agribisnis, seperti jaringan jalan dan transportasi (laut, udara, sungai dan darat) jaringan listrik, air, pelabuhan perikanan dan peternakan, pelabuhan ekspor dan lain-lain.

\section{Sistem Pertanian Terpadu dengan Agrofishery}

Konsep Sistem Pertanian terpadu adalah konsep pertanian yang dapat dikembangkan untuk lahan pertanian terbatas maupun lahan luas. Pada lahan terbatas atau lahan sempit yang dimiliki oleh petani umumnya konsep ini menjadi sangat tepat dikembangkan dengan pola intensifikasi lahan. Lahan sempit akan memberikan produksi maksimal tanpa ada limbah yang terbuang percuma. Sedangkan untuk lahan lebih luas konsep ini akan menjadi suatu solusi mengembangkan pertanian agribisnis yang lebih menguntungkan. Melaiui sistem yang terintegrasi ini akan bermanfaat untuk efisiensi penggunaan lahan, optimalisasi produksi, pemanfaatan limbah, subsidi silang untuk antisipasi fluktuasi harga pasar dan kesinambungan produksi (PT. RAPP dan Universitas Lancang Kuning, 2001). 
Menurut Saputra, (2000) sebagai contoh sederhana pertanian terpadu adalah apabila dalam suatu kawasan ditanam jagung, maka ketika jagung tersebut panen, hasil sisa tanaman merupakan limbah yang harus dibuang oleh petani. Tidak demikian halnya apabila di kawasaan tersebut tersedia ternak ruminansia, limbah tersebut akan menjadi makanan bagi hewan ruminansia tersebut. Hubungan timbal balik akan terjadi ketika ternak mengeluarkan kotoran yang digunakan untuk pupuk bagi tanaman yang ditanam di kawasan tersebut.

Munculnya Integrated Farming Systems (IFS) telah memungkinkan kita untuk mengembangkan sebuah kerangka kerja untuk model pengembangan alternatif untuk memperbaiki kelayakan operasi pertanian berukuran kecil dalam kaitannya dengan yang lebih besar. Sistem pertanian terpadu merupakan kata umum yang digunakan dalam menjelaskan pendekatan pertanian yang lebih terintegrasi dibandingkan dengan pendekatan budidaya pada lahan pertanian pada suatu areal atau tunggal (monokultur). Sistem pertanian yang menggabungkan produksi ternak dengan tanaman pangan atau dengan mengintegrasikan ikan, serta ternak, yang biasanya juga disebut dengan Integrated Biosystems. Integrasi biosistem merupakan serangkaian perusahaan yang saling terkait digunakan sehingga "limbah" dari satu komponen menjadi masukan bagi bagian lain dari sistem, yang mengurangi biaya dan meningkatkan produksi dan / atau pendapatan. SPT bekerja sebagai sistem sistem dan memastikan bahwa limbah dari satu bentuk pertanian menjadi sumber untuk bentuk lain. Karena memanfaatkan limbah sebagai sumber daya, kita tidak hanya menghilangkan limbah tapi juga memastikan peningkatan produktivitas secara keseluruhan untuk keseluruhan sistem pertanian.

Uvaneswaran dan Keerthana, (2015) menjelaskan bahwa pertanian terpadu diperlukan karena membuat hubungan yang kuat antara produksi tanaman pangan dengan kegiatan sekutunya dan menjadi daur ulang yang lebih baik untuk tujuan produktif dalam sistem terpadu terhadap perubahan teknik pertanian untuk produksi maksimum dalam pola tanam dan Memanfaatkan sumber daya dengan lebih baik untuk menjadikan usaha pertanian sebagai usaha yang memberi keuntungan dan kesempatan kerja yang mantap. 
JoIE: Journal of Islamic Economics | Husna Ni'matul Ulya

Hasil penelitian (Uvaneswaran dan Keerthana, 2015) menjelaskan pertanian terpadu adalah pendekatan manajemen keseluruhan pengelolaan keseluruhan yang menggabungkan ekologi lingkungan yang beragam dan sehat dengan tuntutan ekonomi pertanian untuk memastikan pasokan makanan sehat dan terjangkau yang berkelanjutan karena konsep yang dinamis, pastilah relevan di pertanian mana pun, di negara manapun, dan harus selalu menerima perubahan dan kemajuan teknologi. Yang terpenting, pertanian terpadu adalah cara praktis untuk pertanian yang akan menguntungkan semua masyarakat, tidak hanya mereka yang mempraktikkannya. Sistem pertanian terpadu dapat menjadi solusi yang baik bagi pembangunan yaitu dari pertimbangan social, ekonomi serta ekologi untuk mewujudkan produksi pangan pertanian berbasis bisnis.

Selain sistem pertanian terpadu, ada juga beberapa sistem yang perlu pengkajian lebih dalam, (Nurmala, Tati., 2012) menerangkan tentang adanya keterkaitan serta hubungan antara satu sistem dengan sistem lainnya yang terjadi pada sistem pertanian terpadu, ternyata juga terjadi pada sistem pertanian lain, diantaranya yaitu sistem pertanian organic dan sistem pertanian berkelanjutan:

1. Sistem Pertanian Organik, Pemakaian bahan kimia terhadap tanah dan tumbuhan yang berlebihan sangat dihindari pada sistem pertanian organik. Bahan alami yang digunakan dalam pengolahannya adalah pupuk, pupuk yang digunakan seperti pupuk kompos organik. Adanya berbagai manfaat yang terdapat dalam sistem pertanian organik, yaitu pada kegiatan pemupukan yang dilakukan pada tanaman akan menghasilkan tanaman yang bebas dari residu atau sisa-sisa pestisida dan bahan kimia. Produk tanaman jelas lebih sehat dan segar yang dihasilkan dari sistem organik. Kelestarian dan keseimbangan alam dapat dijaga dari tanaman yang dibudidayakan secara organik. Menurut (Sutanto, 2002) mendefinisikan konsep pertanian organik merupakan suatu sistem produksi pertanian yang berazaskan daur ulang secara hayati. Daur ulang hara dapat mampu memperbaiki status kesuburan dan struktur tanah melalui sarana limbah tanaman dan ternak serta limbah lainnya. Teknik pertanian organik merupakan teknik pertanian yang tidak menggunakan bahan kimia (non sintetik), tetapi dengan penggunaan bahan-bahan organik (Pracaya, 2002). 
JoIE: Journal of Islamic Economics | Husna Ni'matul Ulya

2. Sistem Pertanian Berkelanjutan, Dunlap, R. E., \& Van Liere (1992) menjelaskan bahwa pertanian berkelanjutan adalah suatu defenisi tentang tantangan bagi produsen untuk mempertimbangkan dampak jangka panjang yang diawali dari budidaya, interaksi sistem usahatani, dan dinamika sistem pertanian. Dalam konsep ini konsumen didorong agar lebih terlibat dalam partisipan aktif pada sistem pangan. Pada konsep ekologis, pertanian berkelanjutan tanpa penggunaan masukan yang berlebih sangat berkaitan dengan usaha untuk memelihara sistem biologis agar dapat digunakan secara berkelanjutan dan dapat memberikan tingkat luaran yang sama. Kemudian pada tingkatan praktis, dalam konsep ini sangat menuntut pemahaman menyangkut dinamika hara dan energi, interaksi berbagai tanaman dan organisme lain dalam suatu agroekosistem, serta kesetimbangannya dengan keuntungan/pendapatan, dan kebutuhan konsumen serta kepentingan komunitas (Filya Hidayati et.al., 2019).

Gambar 1. Siklus Sistem Pertania Terpadu

The integrated farming system

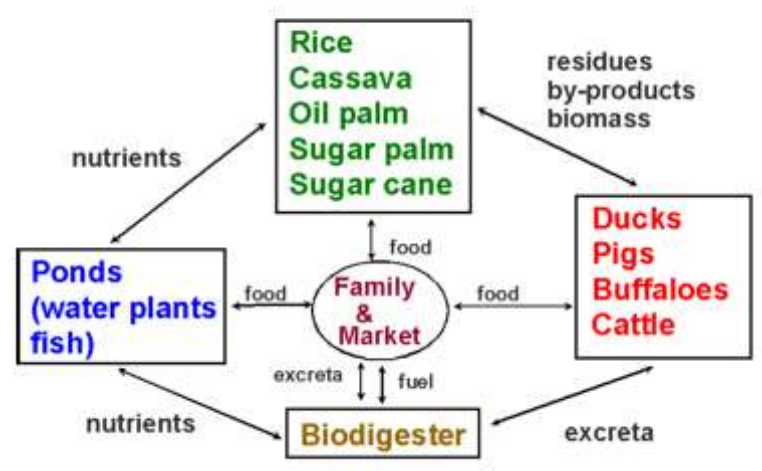

Agrofishery merupakan bentuk kegiatan yang memadukan budidaya perikanan dengan pertanian. Agrofishery atau lebih dikenal dengan istilah mina padi bertujuan untuk meningkatkan efisiensi penggunaan lahan persawahan. Pada dasarnya penerapan pola mina padi atau agrofishery ini adalah untuk mendukung peningkatan produktivitas lahan, meningkatkan pendapatan petani dan meningkatkan kualitas makanan bagi penduduk pedesaan. Penggunaan jenis ikan 
JoIE: Journal of Islamic Economics | Husna Ni'matul Ulya

yang paling umum dipelihara adalah ikan mas. Penebaran ikan dilakukan lebih kurang setelah penanaman. Aspek-aspek teknis dan lain sebagainya akan dituangkan secara detil dalam bentuk dokumen rancangan teknis (Rahmawaty et.al., 2013).

\section{METODE PENELITIAN}

Metode penelitian yang dipakai adalah kualitatif-deskriptif dengan pendekatan Analisis Data Sekunder (ADS). Analisis ini menggunakan data sekunder sebagai data utama, yaitu dengan menggunakan data yang sudah matang yang diperoleh dari instansi atau lembaga. Dalam penelitian ini data sekunder diperoleh dari Bank Indonesia, Badan Pusat Statistik, Dompet Dhuafa, website provinsi Jawa Timur, website Kementerian Pertanian, dan lain-lain, kemudian diolah secara sistematis dan objektif.

Analisis Data Sekunder terdapat prosedur pengumpulan data dan analisis data. Namun demikian tidak semua definisi tentang Analisis Data Sekunder menunjukkannya sebagai suatu metode penelitian. Dijelaskan oleh Johnston (2014), merumuskan Analisis Data Sekunder itu sebagai “any further analysis of an existing dataset which presents interpretations, conclusions or knowledge additional to, or different from, those presented in the first report on the inquiry as a whole and its main results" (analisis lebih lanjut himpunan data yang sudah ada yang memunculkan tafsiran, simpulan atau pengetahuan sebagai tambahan terhadap, atau yang berbeda dari, apa yang telah disajikan dalam keseluruhan dan temuan utama penelitian terdahulu atau semula). Heaton (2004) dalam Andrews et.al. (2012) menjelaskan ADS merupakan suatu strategi penelitian yang memanfaatkan data kuantiatif ataupun kualitatif yang sudah ada untuk menemukan permasalahan baru atau menguji hasil penelitian terdahulu.

Penelitian kualitatif ialah prosedur penelitian yang menghasilkan data deskriptif berupa kata-kata tertulis atau lisan dari orang-orang dan perilaku yang diamati (Bodgan dan Taylor dalam Barowi dan Suwandi, 2009). Sedangkan pendekatan deskriptif bertujuan untuk menggambarkan, meringkaskan berbagai kondisi, berbagai situasi, atau berbagai variabel yang timbul di masyarakat yang 
JoIE: Journal of Islamic Economics | Husna Ni'matul Ulya

menjadi penelitian itu. Kemudian menarik ke permukaan sebagai suatu ciri atau gambaran tentang kondisi, situasi ataupun variabel tertentu (Bungin, 2001). Penelitian kualitatif menekankan pada analisis induktif, bukan analisis deduktif. Data yang dikumpulkan bukan dimaksudkan untuk mendukung atau menolak hipotesis yang telah disusun sebelum penelitian dimulai, tetapi abstraksi disusun sebagai kekhususan yang telah terkumpul dan dikelompokkan bersama lewat proses pengumpulan data yang dilaksanakan secara teliti. Pada penelitian ini, peneliti mengembangkan konsep dan menghimpun fakta, tetapi tidak melakukan pengujian hipotesis melalui perhitungan angka-angka (Sugiyono, 2012).

Wallace Foundation (Workbook B; Secondary Data Analysiswww.wallacefoundation.org) merumuskan langkah-langkah yang dilakukan dalam analisis data sekunder adalah melakukan tahapan sebagai berikut: 1) Menetapkan (mencari-temukan) sumber data/informasi (sekolah, universitas, Dinas Pendidikan, dsb); 2) Mengumpulkan data yang sudah tersedia (dalam “dokumen”); 3) Menormalisasikan data jika diperlukan dan memungkinkan (membuat data dari berbagai sumber sesetara mungkin "menjadi satu bentuk yang sama"); 4) Menganalisis data (misalnya menghitung, mentabulasi, memetakan data-data kuantiatif, atau membandingkan berbagai peraturan dan menelaahnya) (tatangmanguny.wordpress.com). Dalam artikel ini diawali dengan mengumpulkan data sekunder yang dibutuhkan sesuai dengan tema penelitian yang telah dijelaskan sebelumnya, kemudian data yang telah dikumpulkan dalam bentuk dokumen data, setelah data yang diperlukan terkumpul, kemudian mengklasifikasikan data sesuai dengan tujuan analisisnya, kemudian dianalisis menggunakan teori dan kebijakan yang berlaku dan sesuai dengan pokok permasalahan.

\section{HASIL DAN PEMBAHASAN}

\section{Kondisi Pertumbuhan Ekonomi Jawa Timur Pada Kuartal I tahun 2020}

Berdasarkan hasil survei Badan Pusat Statistik (BPS) Propinsi Jawa Timur, kondisi perekonomian Jawa Timur triwulan II mengalami pertumbuhan lebih rendah dibandingkan dengan triwulan I, dikarenakan menurunnya tingkat konsumsi 
JoIE: Journal of Islamic Economics | Husna Ni'matul Ulya

rumah tangga dan LNPRT, penurunan kinerja investasi, penurunan ekspor ke Luar Negeri dan penurunan net ekspor antar daerah. Kontraksi pertumbuhan ekonomi Jawa Timur sebesar 5,90\% (yoy). Penurunan konsumsi masyarakat dipengaruhi oleh adanya regulasi pemerintah berkaitan dengan situasi pandemi Covid-19, yaitu adanya pembatasan berskala besar (PSBB) dan Work From Home (WFH) yang berdampak pada menurunnya konsumsi dikarenakan penurunan daya beli masyarakat. Kemudian penurunan permintaan dari konsumen juga mempengaruhi kinerja investasi swasta (Badan Pusat Statistik, 2020).

Gambar 2. Kondisi Perekonomian Jawa Timur

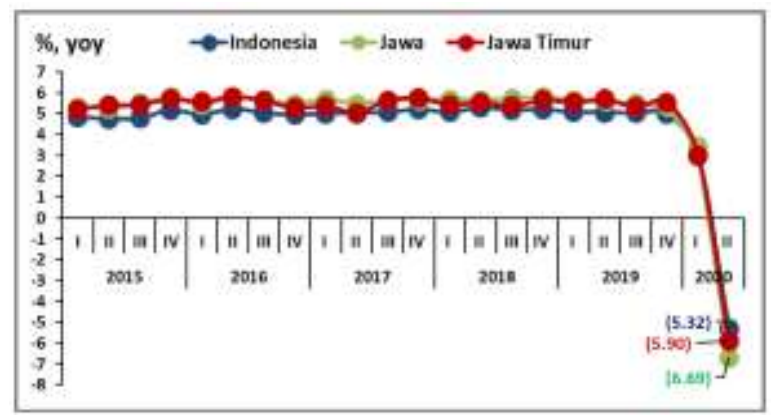

Sumber: Bank Indonesia, 2020.

Menurut Sukirno (2004) pertumbuhan ekonomi dipengaruhi oleh konsumsi, investasi, pengeluaran pemerintah dan juga kinerja perdagangan (ekspor-impor). Peningkatan pada konsumsi, investasi, pengeluaran pemerintah dan juga kinerja perdagangan, maka peningkatan pertumbuhan ekonomi akan terjadi, begitu pula sebaliknya. Kinerja perekonomian dunia sedang mengalami tekanan pada faktorfaktor tersebut karena pendemi, dan akhirnya memerlukan langkah khusus untuk membuat perekonomian menjadi pulih dengan meningkatkan faktor-faktor pengaruh pertumbuhan ekonomi tersebut.

\section{Kondisi Kinerja Sektor Pertanian Jawa Timur Pada Masa Pandemi Covid-19}

Berdasarkan data Badan Pusat Statistik (BPS) sektor pertanian menjadi penyumbang tertinggi terhadap pertumbuhan ekonomi nasional pada triwulan II tahun 2020 yang mengalami penurunan sebesar $-4,19 \%$ (Q to Q) dan secara year on year (yoy) mengalami penurunan sebesar -5,32\%. Menurut data di kompas.com bahwa sektor pertanian mengalami pertumbuhan Pendapatan Domestik Bruto 
JoIE: Journal of Islamic Economics | Husna Ni'matul Ulya

(PDB) pada triwulan I 2020 sebesar 0,02 persen. Bahkan, sektor pertanian juga memiliki kontribusi terbesar ketiga dalam struktur PDB Indonesia dengan porsi sebesar 12,84 persen per kuartal pertama (Q1) pada tahun 2020.

Tabel 1. Kondisi Perekonomian Indonesia pada kuartal II

\begin{tabular}{|c|c|c|c|c|c|c|c|c|c|c|c|c|}
\hline \multirow{2}{*}{ Indikator Malroekonomi Daerah } & \multicolumn{4}{|c|}{2018} & \multirow{2}{*}{2018} & \multicolumn{4}{|c|}{2019} & \multirow{2}{*}{2019} & \multicolumn{2}{|c|}{2020} \\
\hline & 1 & II & III & iv & & I & II & III & IV & & I & II \\
\hline \multicolumn{13}{|c|}{ PDRB (\% yoy) } \\
\hline Sumatera & 4.4 & 4.7 & 4.7 & 4.5 & 4.5 & 4.6 & 4.6 & 4.5 & 4.6 & 4.6 & 3.3 & $(3.0)$ \\
\hline Provinsi Aceh & 3.2 & 5.7 & 4.1 & 5.4 & 4.6 & 3.9 & 3.7 & 3.8 & 5.2 & 4.1 & 3.2 & (1.8) \\
\hline Provinsi Sumatera Utara & 47 & 53 & 5.4 & 5.3 & 5.2 & 5.3 & 5.3 & 5.1 & 5.2 & 5.2 & 4.7 & $(2.4)$ \\
\hline Provinsi Sumatera Barat & 4.7 & 5.1 & 5.3 & 5.5 & 5.2 & 4.9 & 5.0 & 5.2 & 5.1 & 5.1 & 3.9 & $(4.9)$ \\
\hline $\begin{array}{l}\text { Provinsi Riau } \\
\end{array}$ & 29 & 2.4 & 3.0 & 1.3 & 2.4 & 2.9 & 2.8 & 27 & 2.9 & 2.8 & 2.2 & $(3.2)$ \\
\hline Provinsi Kepulauan Riau & 4.5 & 4.6 & 3.7 & 5.5 & 4.6 & 4.8 & 4.6 & 4.9 & 5.2 & 4.9 & 2.1 & $(6.7)$ \\
\hline \begin{tabular}{|l|} 
Provinsi Bengkulu \\
\end{tabular} & 5.1 & 5.1 & 5.0 & 4.8 & 5.0 & 5,1 & 5.0 & 5.0 & 4.8 & 5.0 & 3.8 & $(0.5)$ \\
\hline Provinsi Jambi & 4.6 & 4.8 & 4.7 & 4.9 & 4.7 & 4.7 & 4.9 & 4.5 & 3.6 & 4.4 & 1.9 & (1.7) \\
\hline Provinsi Sumatera Selatan & 5.9 & 6.1 & 6.1 & 6.1 & 6.0 & 5.7 & 5.8 & 5.7 & 5.7 & 5.7 & 5.0 & $(1.4)$ \\
\hline Provinsi Kepulauan Bangka Belitung & 2.5 & 4.5 & 7.1 & 3.7 & 4.5 & 2.8 & 3.4 & 3.0 & 4.0 & 3.3 & 1.3 & $(5.0)$ \\
\hline \begin{tabular}{|l|} 
Provinsi lampung \\
\end{tabular} & 5.1 & 5.3 & 5.2 & 5.4 & 5.2 & 5.2 & 5.6 & 5.2 & 5.1 & 5.3 & 1.7 & $(3.6)$ \\
\hline Jawa & 5.7 & 5.7 & 5.7 & 5.8 & 5.7 & 5.7 & 5.6 & 5.5 & 5.3 & 5.5 & 3.4 & $(6.7)$ \\
\hline \begin{tabular}{|l|} 
Provinsi DKI Jakarta \\
\end{tabular} & 5.9 & 5.9 & 6.4 & 6.4 & 6.2 & 6.2 & 5.5 & 5.9 & 6.0 & 5.9 & 5.1 & $(8.2)$ \\
\hline Provinsi Jawa Barat & 5.8 & 5.5 & 5.9 & 6.0 & 5.7 & 5.4 & 5.7 & 5.1 & 4.1 & 5.1 & 2.7 & $(6.0)$ \\
\hline Provinsi Banten & 5.9 & 5.6 & 5.6 & 5.5 & 5.8 & 5.4 & 5.4 & 5.4 & 5.9 & 5.5 & 3.2 & $(7.4)$ \\
\hline Provinsi lawa Tengah & 5.4 & 5.4 & 5.2 & 5.3 & 5.3 & 5.1 & 5.5 & 5.6 & 5.3 & 5.4 & 2.6 & $(5.9)$ \\
\hline Provinsi DI Yogyakarta & 5.4 & 59 & 6.0 & 7.4 & 6.2 & 7.5 & 6.8 & 6.0 & 6.2 & 6.6 & $(0.2)$ & $(6.7)$ \\
\hline \begin{tabular}{|l} 
Provinsi Jawa Timur \\
\end{tabular} & 5.4 & 55 & 5.4 & 5.6 & 5.5 & 5.5 & 5.7 & 5.3 & 5.5 & 5.5 & 3.0 & (5.9) \\
\hline Kalimantan & 3.3 & 3.4 & 3.6 & 5.3 & 3.9 & 5.2 & 5.4 & 5.7 & 3.7 & 5.0 & 2.3 & $(4.4)$ \\
\hline Provinsi Kalimantan Barat & 5.0 & 5.2 & 4.9 & 5.1 & 5.1 & 5.2 & 5.1 & 5.1 & 4.7 & 5.0 & 2.7 & $(3.4)$ \\
\hline Provinsi Kalimantan Tengah & 4.5 & 5.6 & 6.4 & 6.1 & 5.6 & 6.0 & 7.5 & 5.2 & 6.0 & 6.2 & 2.9 & $(3.2)$ \\
\hline Provinsi Kalimantan Selatan & 5.0 & 4.6 & 5.1 & 5.8 & 5.1 & 4.3 & 4.2 & 4.0 & 3.9 & 4.1 & 4.2 & $(2.6)$ \\
\hline Provinsi Kalimantan Timur & 1.8 & 2.0 & 2.1 & 4.8 & 2.7 & 5.1 & 5,1 & 6.3 & 2.7 & 4.8 & 1.3 & $(5.5)$ \\
\hline Provinsi Kalimantan Utara & 5.8 & 5.0 & 5.6 & 7.7 & 6.1 & 7.2 & 7.9 & 6.6 & 6.0 & 6.9 & 5.0 & $(3,3)$ \\
\hline \begin{tabular}{|c} 
Balinusra \\
\end{tabular} & 3.8 & 3.6 & $(0.7)$ & 4.4 & 2.7 & 4.6 & 4.8 & 5.3 & 5.5 & 5.1 & 0.9 & $(6,3)$ \\
\hline Provinsi Bali & 5.6 & 6.0 & 6.1 & 7.6 & 6.3 & 6.0 & 5.7 & 5.3 & 5.5 & 5.6 & (1.1) & $(11.0$ \\
\hline \begin{tabular}{|l} 
Provinsi Nusa Tenggara Barat \\
\end{tabular} & 0.1 & (1.3) & (14.1) & (1.4) & $(4.5)$ & 1.7 & 2.1 & 6.5 & 5.7 & 4.0 & 3.2 & (1.4) \\
\hline Provinsi Nusa Tenggara Timur & 5.0 & 5.0 & 5.1 & 5,3 & 5.1 & 5.3 & 6.4 & 3.9 & 5.3 & 5.2 & 2.8 & $(2.0)$ \\
\hline Sulampua & 9.8 & 9.9 & 6.8 & 1.2 & 6.8 & 1.6 & 0.6 & 2.3 & 5.2 & 2.4 & 5.7 & $(1.4)$ \\
\hline \begin{tabular}{|l} 
Provinsi Sulawesi Selatan \\
\end{tabular} & 7.3 & 7.4 & 7.2 & 6.4 & 7.1 & 6.6 & 7.4 & 7.2 & 6.5 & 6.9 & 6.7 & $(3.9)$ \\
\hline Provinsi Sulawesi Barat & 55 & 6.8 & 7.4 & 5.3 & 6.2 & 6.0 & 5.1 & 5.2 & 6.4 & 5.7 & 5.7 & $(0.8)$ \\
\hline Provinsi Sulawesi Tenggara & 6.1 & 6.1 & 7.1 & 6.2 & 6.4 & 6.4 & 6.3 & 6.4 & 6.9 & 6.5 & 6.5 & $(2.4)$ \\
\hline Provinsi Sulawesi Tengah & 6.6 & 6.2 & 7.0 & 5.3 & 6.3 & 6.5 & 6.3 & 6.2 & 9.6 & 7.2 & 5.1 & $(0.1)$ \\
\hline $\begin{array}{l}\text { Provinsi Gorontalo } \\
\end{array}$ & 6.1 & 7.4 & 5.2 & 7.2 & 6.5 & 6.8 & 6.7 & 5.7 & 6.5 & 6.4 & 6.3 & $(0.3)$ \\
\hline Provinsi Sulawesi Utara & 6.6 & 5.8 & 5.6 & 6.1 & 6.0 & 6.6 & 5.5 & 5.2 & 5.5 & 5.7 & 6.2 & $(3.9)$ \\
\hline \begin{tabular}{|l|} 
Provinsi Maluku \\
\end{tabular} & 5.4 & 5.5 & 6.4 & 6.4 & 5.9 & 6.3 & 6.1 & 5.3 & 4.7 & 5.6 & 5.1 & $(0.9)$ \\
\hline Provinsi Maluku Utara & 7.9 & 7.3 & 8.2 & 8.2 & 7.9 & 7.7 & 7.5 & 4.1 & 5.4 & 6.1 & 5.7 & $(0.2)$ \\
\hline Provinsi Papua & 26.7 & 23.9 & 6.2 & (18.0) & 7.4 & $(18.7)$ & (23.9) & (15.1) & $(3.7)$ & $(15.7)$ & 3.1 & 4.5 \\
\hline Provinsi Papua Barat & 5.9 & 12.8 & 6.9 & 0.1 & 6.2 & $(0.2)$ & $(0.5)$ & 2.9 & 8.3 & 2.7 & 4.8 & 0.5 \\
\hline
\end{tabular}

Sumber: Bank Indonesia

Perkembangan Lapangan Usaha pertanian mengalami pertumbuhan positif karena bersumber dari panen raya yang terjadi pada bulan April-Mei 2020. Selain itu, produksi aneka cabai dan bawang merah, khususnya di Jawa Barat dan Jawa Timur, mengalami peningkatan seiring kondusifnya cuaca pada triwulan II 2020 sehingga turut mendukung kinerja lapangan usaha pertanian. Di sisi lain, jumlah ekspor pertanian lebih melambat disebabkan penurunan permintaan global sebagai dampak dari pandemi COVID-19. Peningkatan kinerja lapangan usaha pertanian tersebut selama Periode laporan tercermin dari kembali naiknya kapasitas utilisasi sektor pertanian (www.bi.go.id).

Gambar 3. Kinerja Lapangan Usaha Pertanian Jawa Timur (www.bi.go.id) 

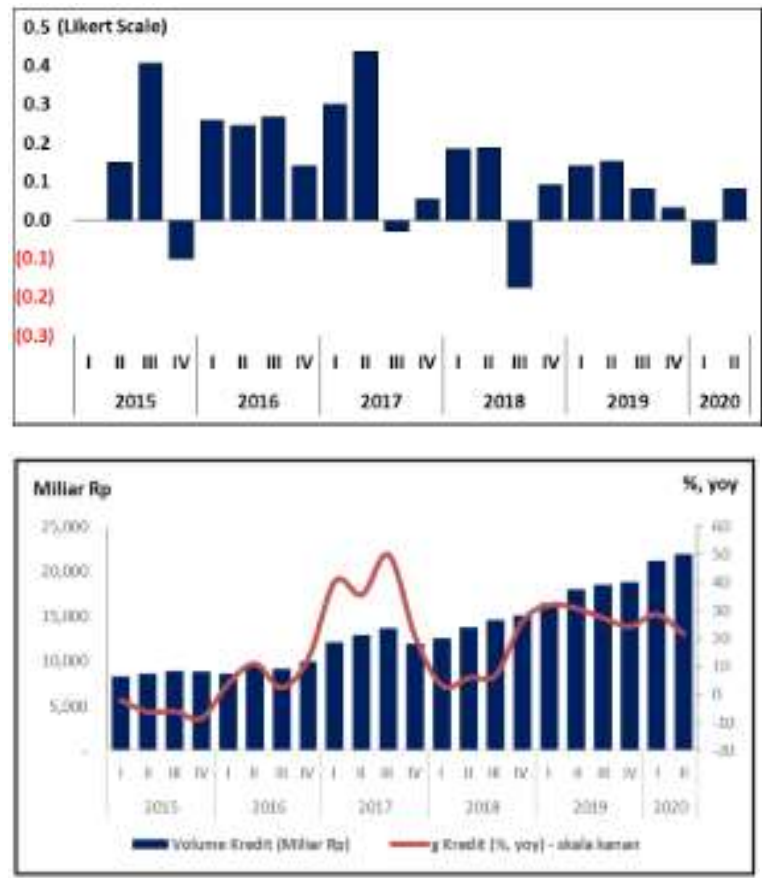

Berdasarkan data tersebut, berdasarkan wawancara kepada pengamat ekonomi Bustanul Arifin (cnbcindonesia.com), bahwa dengan potensi pertanian yang tidak terdampak pandemi covid-19, maka diperlukan kebijakan pertanian yang mendukung perkembangan sektor pertanian yang sesuai dengan kebijakan yang berlaku pada masa pandemi. Dalam rangka menciptakan ketahanan pangan pada masa pandemi dan pemulihan perekonomian serta pengentasan kemiskinan, refocusing anggaran dapat diarahkan kepada sektor yang tetap memiliki pertumbuhan positif serta menciptakan model pengembangan yang sesuai dengan kondisi yang dihadapi. Namun, pada kuartal III diprediksi akan terjadi perlambatan kinerja sektor pertanian dipengaruhi oleh berakhirnya musim panen raya padi. Namun, pergantian musim kemarau basah pada bulan Agustus dan akan dimulainya musim hujan dapat mendukung produksi pertanian lebih baik, sehingga mendukung kinerja Lapangan Usaha pertanian lebih lanjut. Perkiraan panen sejumlah komoditas hortikultura di beberapa daerah sentra di Jawa, serta mulai masuknya musim giling tebu diperkirakan berdampak positif pada kinerja Lapangan Usaha pertanian (www.bi.go.id).

Menurut Mubyarto (1989) pembangunan pertanian bertujuan untuk meningkatkan hasil dan mutu produksi, meningkatkan pendapatan dan taraf hidup 
JoIE: Journal of Islamic Economics | Husna Ni'matul Ulya

petani, peternak dan nelayan, memperluas lapangan kerja dan kesempatan berusaha, menunjang pembangunan industri serta meningkatkan ekspor. Indonesia merupakan negara agragris yang memiliki sumber daya melimpah di bidang pertanian. Sehingga untuk menopang ketahanan ekonomi negara Indonesia dapat memaksimalkan peran sektor pertanian dengan menerapkan inovasi dan pengembangan yang sesuai dengan kebutuhan perkembangan zaman.

Implemetansi Sistem Pertanian Terpadu dengan Sistem Agrofishery (Perikanan dan Pertanian) dengan sistem Budidamber (Budidaya Ikan Lele dalam Ember)

Dompet dhuafa dalam laman daringnya telah melakukan beberapa usaha dalam mewujudkan ketahanan pangan bagi mustahik zakat. Dimana mustahik zakat ini merupakan orang-orang yang berhak menerima zakat, yang masih berada di bawah garis kemiskinan. Program yang dilaksanakan oleh dompet dhuafa merupakan salah satu implementasi dari Sistem pertanian Terpadu. Sistem Pertanian terpadu adalah konsep pertanian yang dapat dikembangkan untuk lahan pertanian terbatas maupun lahan luas. Pada lahan terbatas atau lahan sempit yang dimiliki oleh petani umumnya konsep ini menjadi sangat tepat dikembangkan dengan pola intensifikasi lahan (PT. RAPP dan Universitas Lancang Kuning, 2001).

Sistem Pertanian Terpadu (SPT) dapat diimplementasikan dengan cara menggabungkan antara sistem pertanian, perkebunan, kehutanan, peternakan dan perikanan dan cocok diterapkan untuk lahan yang terbatas, yang mana dalam kegiatan dompet dhuafa tersebut mengadopsi penggabungan antara sistem pertanian dan perikanan dengan memanfaat

Pada bab ini akan dijelaskan tentang implementasi budidaya ikan dalam ember yang menggabungkan sistem budiadaya ikan dan aquaponik dalam satu media, sistem ini telah dilaksanakan oleh salah satu lembaga sosial "dompet dhuafa", sehingga sumber data sekunder yang dipakai dalam pembahasan ini bersumber dari website dan laman youtube dompet dhuafa. Dalam rangka mewujudkan ketahanan pangan dan pemberdayaan ekonomi bagi mustahik, membuat sebuah program pengenalan kepada masyarakat yang bisa dikategorikan dalam implementasi Sistem Pertanian Terpadu (SPT) yang dapat dimanfaatkan di 
JoIE: Journal of Islamic Economics | Husna Ni'matul Ulya

lahan yang terbatas seperti pekarangan dan lingkungan sekitar rumah. Adapun alat dan bahan yang dibutuhkan sebagai berikut:

Gambar 4. Ember yang menjadi media budidamber ukuran 80 liter

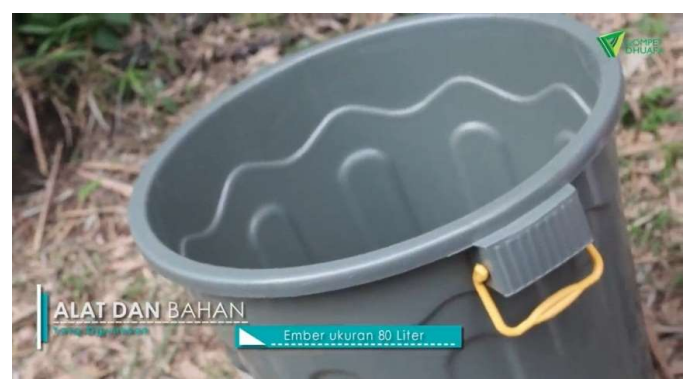

Gambar 5. Kawat drat untuk menambatkan wadah bekas air mineral

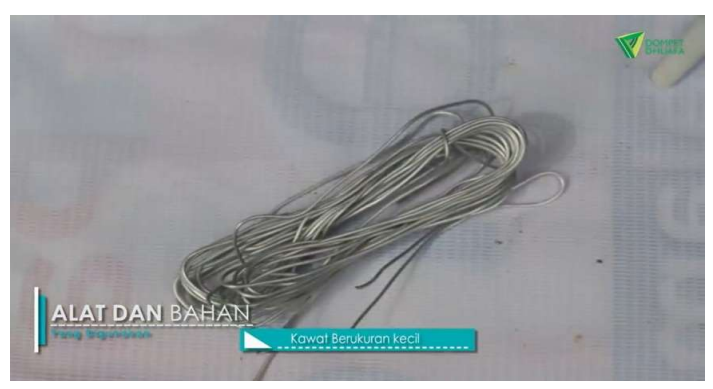

Gambar 6. Kran air dan selotip untuk drainase

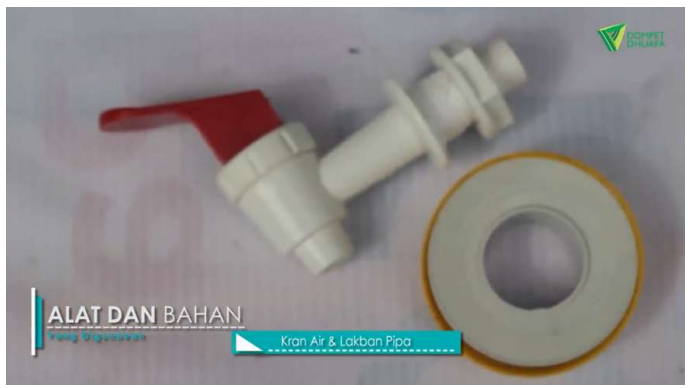

Gambar 7. Cup dan Solder untuk membuat media untuk sayuran/kangkung

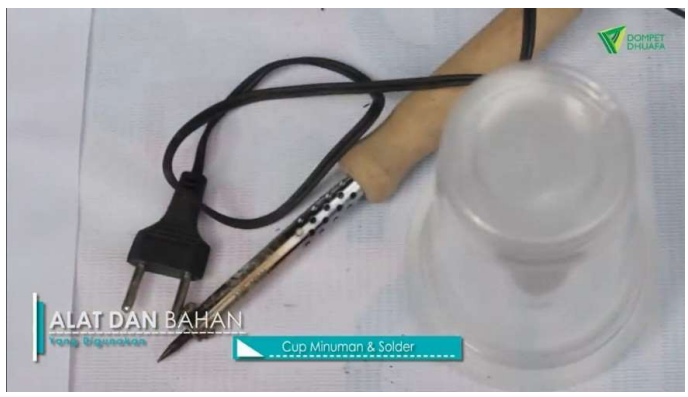

Gambar 8. Arang kayu untuk penunjang kangkung 
JoIE: Journal of Islamic Economics | Husna Ni'matul Ulya

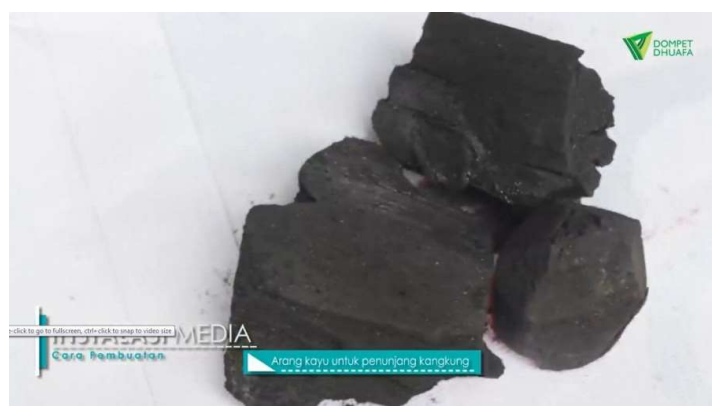

Gambar 9. Probiotik untuk lele

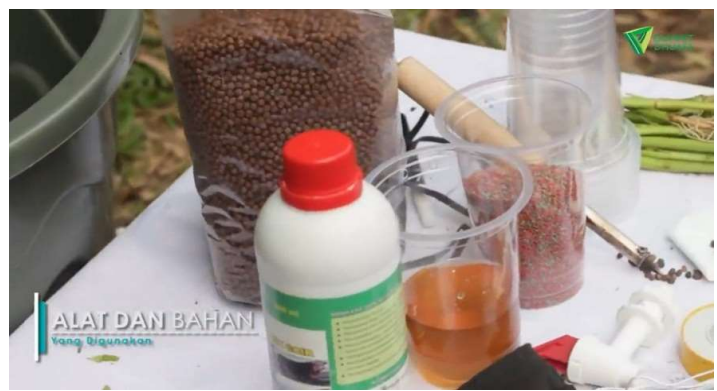

Adapun instalasi media yang digunakan dalam budidaya ikan dan kangkung dalam ember yang sama ini adalah dengan proses sebagai berikut:

Gambar 10. Melubangi ember yang akan digunakan sebagai media

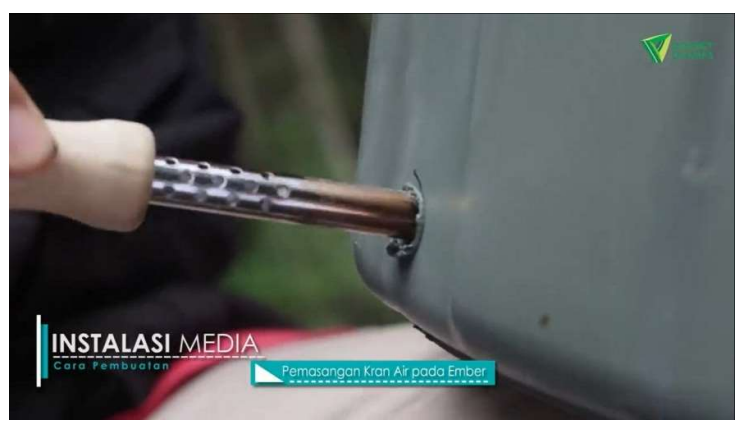

Gambar 11. Melapisi ujung kran dengan selotip, yang digunakan sebagai drainase.

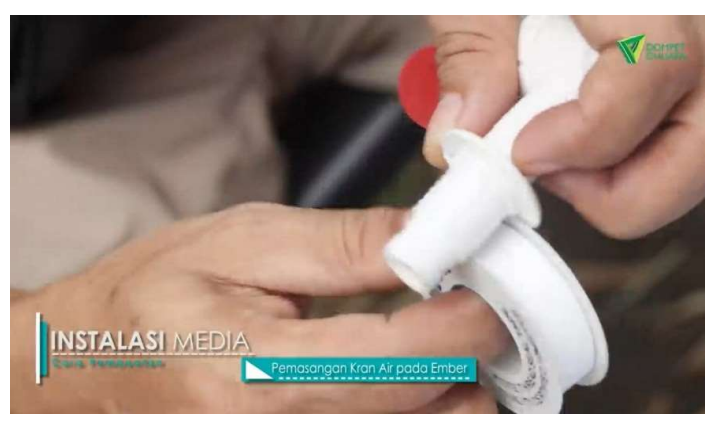


JoIE: Journal of Islamic Economics | Husna Ni'matul Ulya

Gambar 12. Pemasangan kran air pada ember

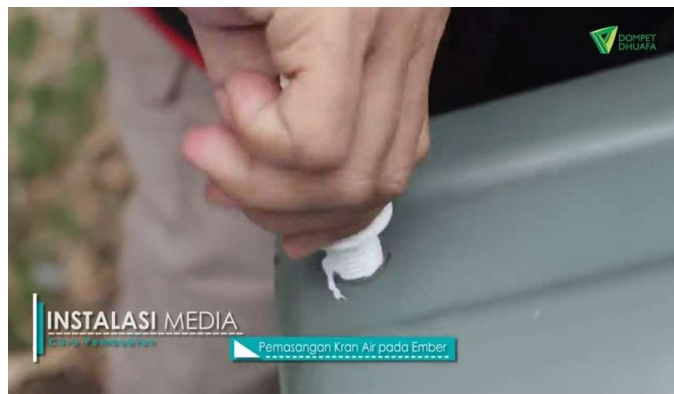

Gambar 13. Pemasangan cup bekas pada ember sebagai media kangkung

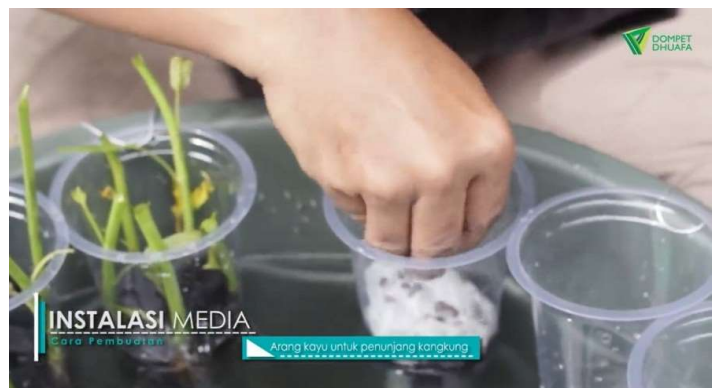

Gambar 14. Air diendapkan selama dua hari

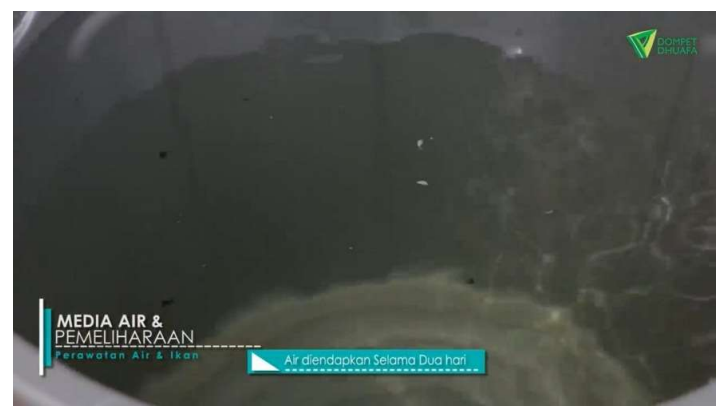


Gambar 15. Pemberian prebiotik ke dalam air

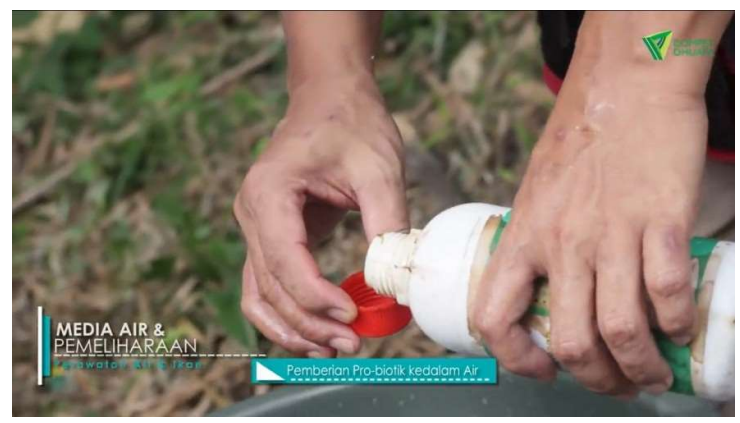

Gambar 16. Penebaran benih lele ukuran $7 \mathrm{~cm}$

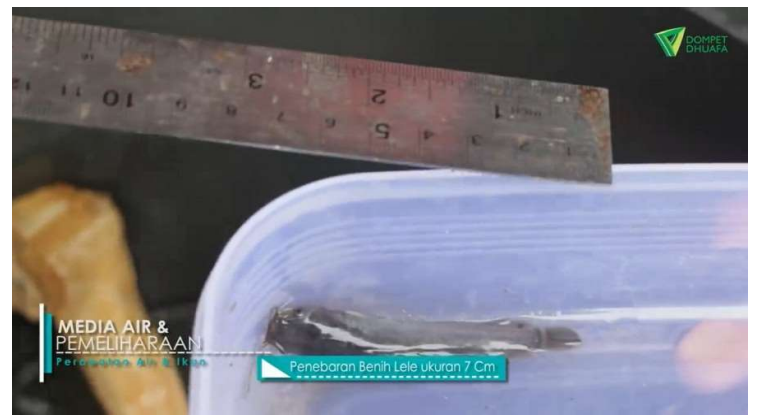

Gambar 17. Penampakan setelah selesai instalasi

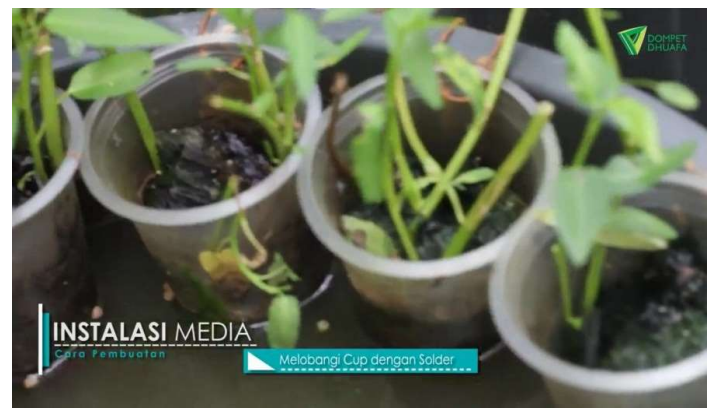

Proses yang dilakukan berdasarkan penjelasan dari dompet duafa adalah sebagai berikut:

Pertama, menyediakan alat dan bahan yang disediakan dan melakukan instalasi dengan menyediakan ember plastik yang berukuran 80 liter dan dilubangi pada bagian bawah dengan bantuan solder, kemudian kran air dipasang sebagai aliran drainase (pembuangan air).

Kedua, cup bekas air mineral diberi lubang dan dipasang di bagian bibir ember secara melingkar dengan menggunakan kawat drat yang telah disediakan untuk sistem aquaponik. 
JoIE: Journal of Islamic Economics | Husna Ni'matul Ulya

Ketiga, melakukan persiapan media air kurang lebih 60 liter yang diendapkan terlebih dahulu selama dua hari dengan menambahkan prebiotik ke dalam air untuk menumbuhkan mikroba yang dapat mengurai kotoran ikan lele agar air tidak mudah berbau dan keruh. Pemberian prebiotik dilakukan satu kali dalam seminggu. Kemudian batang atau benih kangkung di letakkan ke dalam wadah cup yang telah siap, dengan cara meletakkan arang sebagai penunjang batang kangkung, atau dapat dimulai dari benih kangkung. Namun, lama panen akan berbeda pada keduanya, batang kangkung siap dipanen selama kurang lebih 14 hari, sedangkan untuk benih akan lebih lama. Kotoran ikan lele juga berperan sekaligus menjadi pupuk bagi tanaman kangkung.

Keempat, apabila PH sudah memenuhi standar hidup bagi ikan lele sebesar lebih dari 7, maka benih lele siap dimasukkan ke dalam media air yang telah siap, dengan memilih benih lele berukuran 7-8 $\mathrm{cm}$.

Tabel 2. Rata-rata kualitas air Budikdamber adalah: (Enrollment in local colleges, 2005)

\begin{tabular}{lllc}
\hline College & New students & Graduating students & Change \\
\hline & Undergraduate & & \\
Cedar University & 110 & 103 & +7 \\
Elm College & 223 & 214 & +9 \\
Maple Academy & 197 & 120 & +77 \\
Pine College & 134 & 121 & +13 \\
Oak Institute & 202 & 210 & -8 \\
& Graduate & & \\
Cedar University & 24 & 20 & +4 \\
Elm College & 43 & 53 & -10 \\
Maple Academy & 3 & 11 & -8 \\
Pine College & 9 & 4 & +5 \\
Oak Institute & 53 & 52 & +1 \\
\hline Total & $\mathbf{9 9 8}$ & $\mathbf{9 0 8}$ & $\mathbf{9 0}$
\end{tabular}

Sumber: Ippana et.al, 2018

Kelima, melakukan pemeliharaan dengan cara memberikan makan ikan lele berupa pelet dengan durasi tiga kali sehari pada pagi, siang dan malam hari. Penggantian air juga dilakukan secara berkala jika air sudah mulai keruh dan berbau.

Keenam, melakukan penyortiran pada lele yang terkena jamur dan berdasarkan ukuran, agar jamur tidak menular kepada lele yang sehat. Penyortiran 
lele sesuai dengan ukurannya karena untuk menghindari potensi berkurangnya jumlah ikan lele, karena lele bersifat kanibal.

Ketujuh, Lele akan siap dipanen jika telah berumur kurang lebih 2 bulan, dan pada durasi itu juga kangkung dapat dipanen. Menurut Ippana et.al (2018) tanaman kangkung pertama kali panen pada umur 2-3 minggu dengan jumlah panen rata-rata 1 ikat dua ember. Panen berikutnya sekitar 1-2 minggu dengan jumlah panen lebih banyak daripada pertama kali panen sekitar 1 ikat untuk satu ember. Jumlah panen kangkung akan berkurang ketika sudah berumur 3-4 bulan, apabila telah berkurang dapat menanam benih yang baru kembali.

Untuk estimasi biaya yang dibutuhkan dalam menggunakan sistem budikdamber adalah sebagai berikut:

Tabel 3. Estimasi Biaya yang diperlukan untuk sistem Budikdamber

\begin{tabular}{cll}
\hline No & \multicolumn{1}{c}{ Jenis Alat dan Bahan } & Harga (Rp) \\
\hline 1. & Ember ukuran 80 liter & 75.000 \\
\hline 2. & Kran Gallon & 8.000 \\
\hline 3. & 15 cup plastic/cup bekas air mineral 15 pcs & 5.000 \\
\hline 4. & Kawat drat untuk mengikat cup & 5.000 \\
\hline 5. & Arang 1 kantong & 5.000 \\
\hline 6. & 100 benih lele ukuran 7-8 cm (Rp. 350,-/ekor) & 35.000 \\
\hline 7. & Pelet untuk benih lele umur 1 minggu & 5.000 \\
\hline 8. & Pelet kiloan 3 kg / Rp.12.000,- & 36.000 \\
\hline 9. & Pro biotik (bisa dipakai berkali-kali) & 30.000 \\
\hline 10. & Batang kangkung & 0 \\
\hline & Estimasi total biaya yang dibutuhkan & $\mathbf{2 0 4 . 0 0 0}$
\end{tabular}

Sumber: Dompe Dhuafa

Biaya yang diperlukan akan lebih rendah apabila menggunakan bahanbahan bekas dan menggunakan makanan organik, namun dengan makanan organik masih memerlukan penelitian lebih lanjut untuk memastikan lele dapat berkembang seperti yang diharapkan. Sejalan dengan pemikiran Mubyarto (1989) pembangunan pertanian bertujuan untuk meningkatkan hasil dan mutu produksi, meningkatkan pendapatan dan taraf hidup petani. Sistem dengan memanfaatkan media dan potensi yang ada di sekitar rumah diupayakan agar dapat memenuhi kebutuhan pangan masyarakat dan menambah pendapatan masyarakat selama masa pandemi 
JoIE: Journal of Islamic Economics | Husna Ni'matul Ulya

jika pengelolaan diatur dengan baik. Ke depannya jenis ikan dan sayuran yang dipakai dapat bervariasi sehingga hasil panen juga terdapat pilihan yang dapat mencukupi kebutuhan masyarakat yang beraneka ragam.

\section{KESIMPULAN}

Berdasarkan artikel yang telah disusun sebelumnya, maka dapat disimpulkan bahwa:

1. Tingkat pertumbuhan ekonomi di Indonesia mengalami penurunan selama kuartal I dan kuartal II yang disebabkan oleh menurunnya tingkat konsumsi, investasi, dan sektor riil yang menyebabkan pendapatann masyarakat menurun.

Di Jawa Timur tingkat pertumbuhan ekonomi pada kuartal II mengalami penurunan sebesar 5, 90\% (yoy).

2. Dampak pada perkembangan sektor perekonomian di Indonesia sebagian besar mengalami penurunan, kecuali sektor pertanian yang masih mengalami pertumbuhan positif. Di Jawa Timur sektor pertanian masih mengalami pertumbuhan karena bersamaan dengan panen raya, dan ini merupakan potensi yang memerlukan pengembangan strategi baik secara teknis maupun secara dukungan akses modal dan kebijakan pemerintah yang difokuskan pada bidang pertanian.

3. Salah satu upaya pemulihan perekonomian melalui sektor pertanian adalah dengan sistem yang sesuai dengan aturan dalam pencegahan penyebaran virus covid-19, yaitu dengan memanfaatkan lahan sekitar rumah dengan menggunakan Sistem Pertanian Terpadu (SPT), yaitu dengan memadukan sistem pertanian dan perikanan berupa program yang dijalankan oleh dompet dhuafa. Sistem ini disebut dengan budikdamber (budidaya ikan dalam ember), yaitu memelihara ikan lele dan sayuran dalam satu wadah dengan pola tertentu, dan mengusahakan dengan sistem organik yang ramah lingkungan dan kesehatan masyarakat. Hasil dari budidaya dapat digunakan sebagai persediaan pangan keluarga dan dapat dijual kepada masyarakat luas. 
JoIE: Journal of Islamic Economics | Husna Ni'matul Ulya

\section{REFERENSI}

Andrews, Lorraine, et.al. (2012). Classic Grounded Theory to Analyze Secondary Data: Reality and Reflections. The Grounded Theory Review. Volume 11, Issue 1.

Asriani, PS, 2003. "Konsep Agribisnis dan Pembangunan Pertanian, Berkelanjutan di Indonesia”. Jurnal Agrisep. Volume 1.

Basrowi, Suwandi. (2008). Memahami Penelitian Kualitatif. Jakarta: Rineka

Burhan Bungin, Metodolologi Penelitian Sosial: Format-Format Kuantitatif dan

Kualitatif (Surabaya: Airlangga University Press, 2001)

Hanoatubun, Silpa, 2020. “Dampak Covid-19 Terhadap Perekonomian Indonesia”. EduPsyCouns: Journal of Education, Psychology and Counseling. Volume 2 Nomor 1.

Hidayati, F., Yonariza, Y., Nofialdi, N., \& Yuzaria, D. (2020). Analisis Keuntungan dan Kendala Penerapan Konsep Sistem Pertanian Terpadu (SPT) di Indonesia. JIA (Jurnal Ilmiah Agribisnis) : Jurnal Agribisnis dan Ilmu Sosial Ekonomi Pertanian, 5(3), $74 \quad$ - 83. doi:http://dx.doi.org/10.37149/jia.v5i3.11688

Johnston, Melissa P. (2014). Secondary Data Analysis: A Method that which a Time Has Come. Quantitative and Qualitative Methods in Library (QQML).

Mubyarto, 1989. Pengantar Ekonomi Pertanian. Lembaga Penelitian, Pendidikan dan Penerangan Ekonomi dan Sosial (LP3ES). Jakarta.

Nurcholis dan G Supangkat. Pengembangan Integrated Farming System Untuk Pengendalian Alih Fungsi Lahan Pertanian. Prosiding Seminar Nasional. 2011.

Pracaya, 2002. Bertanam Sayuran Organik. PT. Penebar Swadaya. Jakarta.

Perwitasari, Dyah Ayu et.al., 2019. "Penerapan Sistem Akuaponik (Budidaya Ikan Dalam Ember) Untuk Pemenuhan Gizi Dalam Mencegah Stunting Di Desa Gending Kabupaten Probolinggo”. Jurnal Abdi Panca Marga, Vol.1, No. 1. Rahmawaty et. al, 2013. "Sistem Pertanian Terpadu di Lahan Pekarangan Mendukung Ketahanan Pangan Berkelanjutan dan Berwawasan 
JoIE: Journal of Islamic Economics | Husna Ni'matul Ulya

Lingkungan”. Jurnal Online Pertanian Tropik Pasca Sarjana FP USU. Volume 1. Nomor 1.

Rija Sudirja. 2008. Acara Penyuluhan Pertanian, KKNM UNPAD Desa Sawit Kec. Darang dan Kab.Purwakarta, 7 Agustus 2008.

Saputra, RUH, 2000. Pertanian Terpadu sebagai Pilar Kebangkitan Bangsa Indonesia.

Saputri, Shrina Anis Dewi et.al., 2020. "Budidaya Ikan dalam Ember: Strategi Keluarga dalam Memperkuat Ketahanan Pangan di Tengah Pandemi Covid19”. Jurnal Ilmu Pertanian Tirtayasa. Volume 2 Nomor 1. Yogyakarta.

Shofihara, 2020. "PDB Pertanian Naik di Triwulan I, Kementan Prediksi Kenaikan Berlanjut Hingga 2021", https://money.kompas.com/read/2020/05/07/161340626/pdb-pertaniannaik-di- triwulan-i-kementan-prediksi-kenaikan-berlanjut-hingga. Diakses pada September 2020.

Sukirno, Sadono, 2013. Makroekonomi Teori Pengantar. Penerbit Rajawali. Jakarta.

Sugiyono. 2012. Memahami Penelitian Kualitatif. Bandung: ALFABETA

Susetya, Ipanna Enggar et.al., 2018. “Aplikasi Budikdamber (Budidaya Ikan Dalam Ember) Untuk Keterbatasan Lahan Budidaya Di Kota Medan”. ABDIMAS Talenta (3) 2. Medan.

Sutanto, R, 2002. Pertanian Organik: Menuju Pertanian Alternatif dan Berkelanjutan. Kanisius. Yogyakarta.

Uvaneswaran \& Keerthana, (2015). "Integrated Farming System (IFS): A new Entrance for Entrepreneurs". Pezzottaite Journals, 4 (2).

Wallace Foundation. Workbook B: Conductiong Secondary Research. [Other information restricted]. Retrieved June, 2014 online from http://www.wallacefoundation.org/ dalam tatangmanguny.wordpress.com

Www.bi.go.id.

Www.suarasurabaya.net

Www.kompas.id 
JoIE: Journal of Islamic Economics | Husna Ni'matul Ulya

Www.bps.go.id

Www.kementan.go.id

Https://www.youtube.com/user/DhuafaDompet 